\title{
INTERAKSI FAMILI $\times$ LOKASI PADA UJI KETURUNAN GENERASI KEDUA Eucalyptus pellita
}

\author{
Family $\times$ site interaction observed in second-generation progeny trial of Eucalyptus pellita
}

\author{
Fasis Mangkuwibowo ${ }^{1}$, Sapto Indrioko ${ }^{2}$, dan Arif Nirsatmanto ${ }^{3}$ \\ ${ }^{1)}$ Mahasiswa Pasca Sarjana, Prodi Ilmu Kehutanan, \\ Fakultas Kehutanan, Universitas Gadjah Mada \\ J1. Agro No. 1, Bulaksumur, Sleman, Yogyakarta, Indonesia \\ email: fasiswibowo@gmail.com \\ 2) Fakultas Kehutanan, Universitas Gadjah Mada \\ J1. Agro No. 1, Bulaksumur, Sleman, Yogyakarta, Indonesia \\ 3) Balai Besar Penelitian dan Pengembangan Bioteknologi dan Pemuliaan Tanaman Hutan \\ Jl. Palagan Tentara Pelajar Km. 15, Purwobinangun, Pakem, Sleman, Yogyakarta, Indonesia
}

Tanggal diterima: 4 Desember 2017, Tanggal direvisi: 28 Desember 2017, Disetujui terbit: 17 April 2018

\begin{abstract}
The interaction assessment of genotype and environment is necessary to find out an effective selection strategy in progeny trial, particularly in advanced generations. This study aims to observe the effect of family $\times$ site interaction in second generation progeny trial of Eucalyptus pellita planted at two locations: Wonogiri, Central Java and Pelaihari, South Kalimantan. The trials design were completely randomized block design (CRBD) with 49 families, 6-10 blocks, 5 tree-plot and $4 \mathrm{~m} \times 1.5 \mathrm{~m}$ spacing. Data measurements included height, diameter at breast height, and stem volume at two and four years age. The study results showed that the families had significant differences $(p<0.01)$ for all measured traits at two and four years age, but the family and site interaction was not statistically significant. Family heritability across the two sites were moderate to high for all traits with the type $B$ genetic correlation ranged from 0.67 to 0.94 . Heritability and genetic correlation tended to be higher as tree getting older. Less than $16 \%$ of families showed an interactive rank changes in the two locations based on multiple-traits selection index. In general, family selection by combining data from the two sites of progeny trial provided higher genetic gain than those by indirect selection, but it was varied to those direct selection on each site. Therefore, these results imply that, the strategy for family selection by combining data from the two sites of progeny trials should be practiced in appropriate combination and direction by considering the magnitude of genetic variation.
\end{abstract}

Keywords: multi site analysis, genetic parameters, tree improvement, family selection

\begin{abstract}
ABSTRAK
Pengaruh interaksi genotipe dengan lingkungan perlu diamati untuk menetapkan strategi seleksi yang efektif dalam plot uji keturunan, khususnya pada generasi tingkat lanjut. Penelitian ini bertujuan untuk melakukan pengamatan pengaruh interaksi famili $\times$ lokasi pada uji keturunan generasi kedua jenis Eucalyptus pellita yang dibangun di dua lokasi: Wonogiri, Jawa Tengah dan Pelaihari, Kalimantan Selatan. Sebanyak 49 famili diuji menggunakan rancangan acak lengkap berblok (RALB), 6-10 blok, 5 pohon per plot dan jarak tanam $4 \mathrm{~m} \times 1,5$ m. Pengukuran data meliputi tinggi, diameter setinggi dada, dan volume batang pada umur 2 dan 4 tahun. Hasil penelitian menunjukkan bahwa famili yang diuji berbeda nyata $(p<0,01)$ pada seluruh sifat yang diamati, sedangkan interaksi famili $\times$ lokasi tidak berbeda nyata. Nilai heritabilitas famili berkisar sedang - tinggi pada semua sifat dengan nilai Tipe B korelasi genetik berkisar 0,67-0,94. Nilai heritabilitas dan korelasi genetik cenderung semakin tinggi seiring dengan bertambahnya umur tanaman. Kurang dari 16\% dari famili yang diuji menunjukkan perubahan rangking yang interaktif antarlokasi berdasarkan nilai indeks seleksi multi-sifat. Secara umum seleksi famili berdasarkan gabungan data dari kedua lokasi plot uji keturunan menunjukkan nilai perolehan genetik yang lebih tinggi dibandingkan seleksi tidak langsung, namun bervariatif terhadap seleksi langsung pada masing-masing lokasi. Hal ini memberikan implikasi bahwa strategi seleksi famili dengan penggabungan data dari dua lokasi yang diuji perlu dilakukan pada kombinasi dan arah yang tepat dengan memperhatikan besarnya variasi genetik yang ada.
\end{abstract}

Kata kunci: analisa multi lokasi, parameter genetik, pemuliaan pohon, seleksi famili 


\section{PENDAHULUAN}

Oleh karena adanya serangan hama dan penyakit yang serius pada Acacia mangium sebagai spesies andalan hutan tanaman industri dewasa ini, ekaliptus telah menjadi spesies pengganti yang banyak ditanam pada hutan tanaman industri di Indonesia dan Malaysia (Brawner et al., 2015; Harwood, Hardiyanto, \& Yong, 2015; Harwood \& Nambiar, 2014; Tarigan, Roux, Van Wyk, Tjahjono, \& Wingfield, 2011). Terdapat peningkatan luas hutan tanaman ekaliptus yang cukup signifikan di dunia dan saat ini tercatat mencapai 20 juta hektar (Harwood et al., 2015). Eucalyptus pellita merupakan salah satu spesies ekaliptus yang banyak ditanam di Indonesia, dan upaya peningkatan produktivitasnya terus ditingkatkan baik melalui pemuliaan generasi tingkat lanjut maupun aplikasi silvikultur intensif (Brawner, Bush, Macdonell, Warburton, \& Clegg, 2010; Hardiyanto, 2003; Hung et al., 2014; Kurinobu \& Rimbawanto, 2002; Pinyopusarerk \& Harwood, 2010). Sebagai antisipasi penanaman E. pellita pada berbagai kondisi lahan tanam yang bervariasi (iklim, jenis dan kesuburan tanah), kegiatan pemuliaan tanaman dilaksanakan melalui pembangunan plot uji keturunan di beberapa lokasi dengan kondisi lingkungan yang berbeda.

Seleksi merupakan salah satu tahapan penting dalam proses pemuliaan tanaman untuk mendapatkan benih yang unggul (Zobel \& Talbert, 1984). Kegiatan seleksi dilaksanakan melalui pemilihan pohon induk yang unggul secara genetik di dalam uji keturunan sehingga mampu menghasilkan keturunan yang baik. Salah satu tolok ukur terpenting dalam pelaksanaan seleksi adalah diperolehnya perolehan genetik (genetic gain) dan peningkatan produktivitas tanaman. Namun demikian terdapat banyak faktor yang dapat mempengaruhi keberhasilan dan efektivitas seleksi, khususnya berkaitan dengan strategi seleksi pada sebaran lokasi uji keturunan yang berbeda dan strategi pemanfaatan benih unggul yang akan dihasilkan dari program pemuliaan.

Adanya interaksi genetik dengan lingkungan merupakan salah satu faktor yang dapat mempengaruhi efektivitas seleksi. Pengaruh interaksi ini bisa diamati melalui besarnya variasi yang terjadi pada interaksi famili $\times$ lokasi di dalam uji keturunan yang dibangun pada beberapa lokasi yang berbeda. Pengaruh interaksi famili $\times$ lokasi terhadap efektivitas seleksi akan semakin nyata apabila antarlokasi uji keturunan memiliki perbedaan kondisi lingkungan yang ekstrem (Zobel \& Talbert, 1984), khususnya untuk mengantisipasi kebutuhan akan ketersediaan lahan tanam yang semakin meningkat. Penelitian telah dilakukan untuk mengetahui pengaruh interaksi famili $x$ lokasi pada uji keturunan generasi pertama jenis E. pellita (Leksono, 2009). Namun demikian observasi interaksi famili $\times$ lokasi belum dilaporkan pada uji keturunan generasi kedua. Disamping perbedaan karena lokasi pengujian, efek dari seleksi selama siklus pemuliaan generasi pertama diduga juga akan memberikan pengaruh terhadap besarnya interaksi famili $\times$ lokasi pada pemuliaan generasi kedua (Brawner et al., 2010).

Dalam penelitian ini disajikan hasil pengamatan pengaruh interaksi famili $\times$ lokasi pada uji keturunan generasi kedua E. pellita yang dibangun di dua lokasi yang memiliki karakteristik klimatologis dan tanah yang berbeda. Hasil penelitian diharapkan akan memberikan manfaat dalam memperbaiki strategi seleksi pada kebun benih E. pellita sehingga potensi perolehan genetik dan produktivitasnya bisa lebih ditingkatkan pada kondisi lahan tanam yang bervariasi, baik pada lahan yang optimal maupun sub optimal bagi pertumbuhan E. pellita.

\section{BAHAN DAN METODE}

\section{A. Bahan}

Uji keturunan penyerbukan bebas (open pollinated progeny trial) generasi kedua 
E. pellita yang dibangun Balai Besar Penelitian dan Pengembangan Bioteknologi dan Pemuliaan Tanaman Hutan Yogyakarta di dua lokasi, yaitu di Wonogiri, Jawa Tengah dan Pelaihari, Kalimantan Selatan (Leksono, Nirsatmanto, Setyaji, \& Surip, 2005). Uji keturunan kemudian secara bertahap dikonversi menjadi plot uji keturunan melalui penjarangan. Penjarangan seleksi melalui penebangan pohon dalam plot (within-plot selection) telah dilakukan pada masing-masing uji keturunan pada umur 2 tahun (sesaat setelah pengukuran pada umur 2 tahun) dengan intensitas penjarangan sebesar $40 \%$ (Wonogiri) dan $60 \%$ (Pelaihari). Deskripsi uji keturunan generasi kedua E. pellita dan kondisi lingkungan disajikan pada Tabel 1 .

Tabel 1. Deskripsi uji keturunan generasi kedua E. pellita, kondisi klimatologis dan jenis tanah

\begin{tabular}{lll}
\hline \multirow{2}{*}{ Uraian } & \multicolumn{1}{c}{ Wonogiri } & \multicolumn{1}{c}{ Lokasi } \\
\cline { 2 - 3 } Geografis & \multicolumn{1}{c}{$07^{0} 32^{\prime}-8^{0} 15^{\prime} \mathrm{LS}$} & $3^{0} 58^{\prime}-4^{0} 08^{\prime} \mathrm{LS}$ \\
& $110^{0} 41^{\prime}-111^{\circ} 18^{\prime} \mathrm{BT}$ & $114^{0} 37^{\prime}-114^{0} 42^{\prime} \mathrm{BT}$ \\
Ketinggian tempat (m dpl) & $141 \mathrm{~m}$ & $15 \mathrm{~m}$ \\
Tipe iklim & $\mathrm{C}(\mathrm{Schmidt}$ dan Ferguson) & $\mathrm{B}$ (Schmidt dan Ferguson) \\
Curah hujan (mm/tahun) & $1.878 \mathrm{~mm} /$ tahun & $2.730 \mathrm{~mm} /$ tahun \\
Suhu ( $\left.{ }^{\circ} \mathrm{C}\right)$ & $21^{0} \mathrm{C}-33^{0} \mathrm{C}$ & $2{ }^{0} \mathrm{C}-33^{0} \mathrm{C}$ \\
Jenis tanah & Vertisols & Ultisols \\
Tahun tanam & 2004 & 2003 \\
Jumlah famili & 49 & 49 \\
Provenans & Indonesia, Papua Nugini & Indonesia, Papua Nugini \\
& rancangan acak lengkap berblok & rancangan acak lengkap berblok \\
Rancangan percobaan & (RALB), 4 blok, masing-masing plot & (RALB), 10 blok, masing-masing \\
& 5 pohon per plot) & plot 5 pohon per plot) \\
Jarak tanam & $4 \times 1,5 \mathrm{~m}$ & $4 \times 1,5 \mathrm{~m}$ \\
\hline
\end{tabular}

Sumber: Leksono et al. (2005)

\section{B. Metode penelitian}

\section{Pengumpulan data}

Pada masing-masing uji keturunan, tinggi total tanaman dan diameter setinggi dada diukur pada umur 2 dan 4 tahun. Pada umur 2 tahun pengukuran tinggi dan diameter dilakukan sebelum penjarangan pertama dilaksanakan. Pengukuran tinggi tanaman dilaksanakan menggunakan galah ukur, sedangkan untuk diameter menggunakan pita ukur diameter (diameter tape). Data tinggi dan diameter digunakan untuk menghitung volume batang dengan rumus (Wahyu Edi, komunikasi pribadi, 7 Oktober 2015):

$$
\begin{aligned}
& \mathrm{V}=\exp (-10,8706) \times \mathrm{T}^{1,2596} \times \mathrm{D}^{1,93168} \\
& \text { keterangan: } \\
& \mathrm{D} \quad \text { : diameter setinggi dada }(\mathrm{cm}) \\
& \mathrm{T} \quad \text { : tinggi pohon (meter) }
\end{aligned}
$$

\section{Analisis data}

a) Analisis Varians

Data rata-rata plot, yaitu rata-rata semua individu tanaman dari setiap famili di dalam setiap blok, dilakukan analisis varians menggunakan dua model, yaitu 1) analisa data satu lokasi dan 2) analisa data multi-lokasi (Johnson, 1992; Matheson \& Raymond, 1984): Satu lokasi

$$
\begin{aligned}
& \mathrm{Y}_{i j}=\mu+\mathrm{B}_{i}+\mathrm{F}_{j}+\mathrm{E}_{i j} \\
& \text { dimana: } \\
& \mathrm{Y}_{i j} \text { : pengamatan rata-rata plot (famili ke- } \\
& j \text { di dalam blok ke- } i \text { ) } \\
& \mu \quad \text { : rata-rata umum } \\
& \mathrm{B}_{i}: \text { pengaruh blok ke- } i \text {, } \\
& \mathrm{F}_{j} \quad \text { : pengaruh famili ke-j } \\
& \mathrm{E}_{i j}: \text { galat }
\end{aligned}
$$




\section{Multi-lokasi}

$$
\begin{array}{cll}
\mathrm{Y}_{i j k}=\mu+\mathrm{L}_{i}+\mathrm{B}(\mathrm{L})_{j i}+\mathrm{F}_{k}+\mathrm{FL}_{k i}+\mathrm{E}_{i j k} \ldots \ldots \ldots \ldots . . .(3) \\
\text { dimana }: & \text { pengamatan rata-rata plot (famili } \\
\mathrm{Y}_{i j k} \quad: \quad & \text { ke- } k \text { di dalam blok ke- } j \text { dan lokasi } \\
& \text { ke- } i, \\
\mu \quad: & \text { rata-rata umum } \\
\mathrm{L}_{i} \quad: & \text { pengaruh lokasi ke- } i \\
\mathrm{~B}(\mathrm{~L})_{j i}: & \text { pengaruh blok ke-j dalam lokasi } \\
& \text { ke- } i \\
\mathrm{~F}_{k} \quad: & \text { pengaruh famili ke- } k \\
\mathrm{FL}_{k i} \quad: & \text { pengaruh interaksi famili ke- } k \text { dan } \\
& \text { lokasi ke- } i \\
\mathrm{E}_{i j k} \quad: \quad & \text { galat }
\end{array}
$$

Semua variabel dalam penelitian ini dianggap sebagai pengaruh random/random effect, kecuali variabel blok dan lokasi.

b) Nilai heritabilitas

Nilai heritabilitas famili dihitung pada satu lokasi dan multi-lokasi dengan menggunakan rumus masing-masing sebagai berikut (Johnson, 1992; Wright, 1976):

\section{Satu lokasi}

$$
\mathrm{h}_{f}^{2}=\sigma_{f}^{2} /\left[\sigma_{e}^{2} / \mathrm{B}+\sigma_{f}^{2}\right]
$$

\section{Multi-lokasi}

$$
\begin{aligned}
& \mathrm{h}_{f}^{2}=\sigma_{f}^{2} /\left[\sigma_{f}^{2}+\sigma_{f l}^{2} / \mathrm{L}+\sigma_{e}^{2} / \mathrm{BL}\right] \\
& \text { dimana: } \\
& \mathrm{h}_{f}^{2} \quad: \quad \text { heritabilitas famili } \\
& \sigma_{f}^{2} \quad \text { : komponen varians famili } \\
& \sigma_{f l}^{2}: \text { komponen varians interaksi famili } \\
& \times \text { lokasi } \\
& \sigma_{e}^{2} \quad \text { : komponen varians eror } \\
& \text { B : jumlah blok per lokasi } \\
& \text { L : jumlah lokasi }
\end{aligned}
$$

c) Korelasi genetik

Estimasi korelasi genetik antarsifat pada satu lokasi dihitung dengan rumus sebagai berikut:

$$
\begin{aligned}
& \mathrm{r}_{a}=\sigma_{f(\mathrm{xy})} /\left(\sigma_{f(\mathrm{x})}^{2} \times \sigma_{f(\mathrm{y})}^{2}\right)^{1 / 2} \\
& \text { dimana: } \\
& \mathrm{r}_{a} \quad \text { : korelasi genetik } \\
& \sigma_{f(\mathrm{x})}^{2} \text { : komponen varians famili sifat ke- } x \\
& \sigma_{f(\mathrm{y})}^{2} \text { : komponen varians famili sifat ke- } y \\
& \sigma_{f(x y)}: \text { komponen kovarians famili sifat } \\
& \text { ke- } x \text { dan sifat ke- } y
\end{aligned}
$$

Estimasi korelasi genetik Type-B untuk sifat yang sama antarlokasi ke- $x$ dan ke- $y$ dihitung dengan rumus sebagai berikut (Yamada, 1962):

$$
\begin{aligned}
& \mathrm{r}_{\mathrm{B}}=\sigma_{f}^{2} /\left(\sigma_{f}^{2}+\sigma_{f l}^{2}\right) \\
& \text { dimana: } \\
& \sigma_{f}^{2}: \text { komponen varians famili } \\
& \sigma_{f l}^{2}: \text { komponen varians interaksi famili } \\
& \times \text { lokasi }
\end{aligned}
$$

d) Perolehan genetik

Koefisien bobot masing-masing sifat dalam penghitungan indeks seleksi untuk penentuan rangking famili pada satu lokasi dan multi-lokasi dihitung menggunakan prosedur (Burdon, 1979):

$$
\begin{aligned}
& \mathrm{b}=\mathrm{P}_{f}^{-1} \times \mathrm{G}_{f} \times \mathrm{a} \\
& \text { dimana: }
\end{aligned}
$$

Selanjutnya taksiran nilai perolehan genetik masing-masing sifat sebagai respons seleksi dihitung dengan menggunakan rumus (Hazel, 1943):

$$
\begin{aligned}
& \Delta \mathrm{g}=\mathrm{i}^{\times} \mathrm{G}_{f}^{\prime} \times \mathrm{b} /\left(\mathrm{b}^{\prime} \times \mathrm{P}_{f} \times \mathrm{b}\right)^{1 / 2} \\
& \text { dimana: } \\
& \text { i : intensitas seleksi (diasumsikan } 1 \\
& \text { untuk memudahkan } \\
& \text { penghitungan) } \\
& \mathrm{G}_{f} \text { : matriks varians dan kovarian } \\
& \text { genetik } \\
& \mathrm{P}_{f} \text { : matriks varian dan kovarian } \\
& \text { fenotipik } \\
& \text { b : vektor koefisien bobot masing- } \\
& \text { masing sifat }
\end{aligned}
$$

Untuk mengetahui respons perolehan genetik hasil seleksi tidak langsung (seleksi berdasarkan lokasi yang lain), ukuran matrik $\mathrm{G}_{f}{ }^{\prime}$ yang digunakan adalah $6 \times 6$ yang tersusun atas 
matrik varians dan kovarians genetik dari masing-masing lokasi berdimensi $3 \times 3$ dan matrik Type-B kovarians berdimensi $3 \times 3$ (Nirsatmanto et al., 1996).

\section{HASIL DAN PEMBAHASAN}

\section{A. Pertumbuhan tanaman}

Pertumbuhan uji keturunan E. pellita generasi kedua di Pelaihari, Kalimantan Selatan dan Wonogiri, Jawa Tengah umur 2 dan 4 tahun disajikan pada Tabel 2. Secara umum uji keturunan di Pelaihari menunjukkan pertumbuhan tinggi dan diameter $2-3$ kali lebih cepat dibandingkan dengan di Wonogiri. Hal ini disebabkan adanya perbedaan tapak (jenis tanah dan kondisi klimatologis) di antara kedua lokasi. Pelaihari memiliki tapak (jenis tanah) yang lebih baik untuk pertumbuhan
E. pellita dibandingkan Wonogiri (Leksono, 2009; Sunarti, Na'iem, Hardiyanto, \& Indrioko, 2013). Uji keturunan E. pellita generasi kedua di Pelaihari menunjukkan pertumbuhan yang lebih baik dibandingkan dengan uji keturunan generasi pertama pada beberapa tapak di Sumatera. Hardiyanto (2003) melaporkan pertumbuhan E. pellita umur 2 tahun dari beberapa provenans yang ditanam di Sumatera Selatan pada tanah podsolik dan curah hujan $2700 \mathrm{~mm} /$ tahun berkisar $8 \mathrm{~m}$ - 9,8 m (tinggi) dan 7,2 - 8,3 cm (diameter). Sementara itu Brawner et al. (2010) melaporkan pertumbuhan E. pellita umur 2 tahun di Sumatera Utara pada tanah andisol dan curah hujan 2000-3000 $\mathrm{mm} /$ tahun berkisar 7,8 $\mathrm{m}-9,2 \mathrm{~m}$ (tinggi) dan $8,6 \mathrm{~cm}-9 \mathrm{~cm}$ (diameter).

Tabel 2. Pertumbuhan tananam uji keturunan generasi kedua Eucalyptus pellita di Pelaihari dan Wonogiri umur 2 dan 4 tahun

\begin{tabular}{|c|c|c|c|c|}
\hline \multirow{2}{*}{ Sifat } & \multicolumn{2}{|c|}{ Pelaihari } & \multicolumn{2}{|c|}{ Wonogiri } \\
\hline & 2 tahun & 4 tahun & 2 tahun & 4 tahun \\
\hline Tinggi (m) & $12,17 \pm 0,05$ & $18,81 \pm 0,98$ & $4,02 \pm 0,05$ & $10,50 \pm 0,09$ \\
\hline Diameter batang $(\mathrm{cm})$ & $9,59 \pm 0,05$ & $16,16 \pm 0,08$ & $3,76 \pm 0,05$ & $8,94 \pm 0,09$ \\
\hline Volume batang $\left(\times 10^{-3} \mathrm{~m}^{3}\right)$ & $38,74 \pm 0,49$ & $175,85 \pm 2,54$ & $1,96 \pm 0,08$ & $28,50 \pm 0,74$ \\
\hline
\end{tabular}

Walaupun menunjukkan pertumbuhan yang berbeda (Tabel 2), riap pertumbuhan tinggi dari umur 2 tahun ke 4 tahun di kedua plot uji keturunan menunjukkan tren yang sama, yaitu berkisar $\pm 6 \mathrm{~m}$. Hal ini menunjukkan bahwa perbedaan pertumbuhan diduga tidak terlalu mempengaruhi ekspresi riap tumbuh tinggi tanaman pada dua rentang waktu pengamatan di dalam plot uji keturunan generasi kedua E. pellita. Tekanan terhadap pertumbuhan tinggi tanaman di Wonogiri diduga lebih disebabkan karena kondisi tapak, khususnya pada tahap awal pertumbuhan tanaman. Sementara untuk diameter batang, terdapat perbedaan riap pada kisaran $\pm 5 \mathrm{~cm}$ untuk Wonogiri dan $\pm 7 \mathrm{~cm}$ untuk Pelaihari. Begitu pula volume batang memberikan perbedaan riap pada kisaran angka yang lebih besar, yaitu $\pm 26\left(\times 10^{-3}\right) \mathrm{m}^{3}$ untuk lokasi di Wonogiri dan $\pm 140\left(\times 10^{-3}\right) \mathrm{m}^{3}$ untuk lokasi di Pelaihari.

Penjarangan seleksi di dalam plot diduga juga telah memberikan pengaruh pada pertumbuhan riap diameter batang E. pellita umur 4 tahun. Rasio penjarangan seleksi plot uji keturunan di Wonogiri hanya 40\% (masih tersisa 3 pohon per plot), sementara itu penjarangan seleksi di Pelaihari sebesar $60 \%$ (masih tersisa 2 pohon per plot). Hal ini mengindikasikan bahwa tanaman E. pellita sangat sensitif terhadap kerapatan tegakan dan kompetisi antar individu tanaman. Pertumbuhan riap diameter selanjutnya juga telah mempengaruhi besarnya riap volume batang (Tabel 2). Hal ini diduga karena volume batang dihitung sebagai fungsi dari tinggi tanaman dan diameter batang dimana proporsi diameter batang memberikan pengaruh yang lebih besar 
dibandingkan tinggi, sebagaimana terlihat pada persamaan yang digunakan (Rumus 1).

Optimalisasi pertumbuhan diameter dan kerapatan tegakan nampaknya akan sangat menguntungkan dalam peningkatan volume tegakan E. pellita. Clutter, Fortson, Pienaar, Britste, dan Bailey (1983) menyatakan bahwa volume tegakan tidak hanya berhubungan dengan volume pohon tetapi juga berhubungan dengan faktor lain, seperti pertumbuhan diameter, kerapatan tegakan dan tempat tumbuh.

\section{B. Analisis satu lokasi}

\section{Analisis varians}

Hasil analisis varians terhadap tinggi, diameter dan volume batang pada uji keturunan generasi kedua E. pellita disajikan pada Tabel 3. Famili memberikan pengaruh yang nyata pada seluruh sifat yang diamati, kecuali sifat diameter umur 2 tahun pada plot uji keturunan di Wonogiri. Hal ini menunjukkan bahwa variasi genetik yang diekspresikan oleh pertumbuhan famili yang diuji adalah cukup besar, walaupun kedua lokasi plot uji memiliki tingkat kesuburan dan kondisi tapak yang sangat berbeda.
Sementara itu ekspresi variasi genetik belum terlihat secara nyata pada sifat diameter umur 2 tahun di Wonogiri.

Variasi genetik yang besar pada uji keturunan E. pellita juga disebabkan oleh komposisi materi genetik dan pola rancangan percobaan yang digunakan. Uji keturunan dibangun menggunakan famili-famili dengan sebaran populasi asal yang cukup lebar yang meliputi provenans dari Indonesia dan Papua Nugini (Tabel 1). Sebagaimana dilaporkan pada beberapa studi bahwa $E$. pellita memiliki variasi genetik antar populasi yang besar (House \& Bell, 1996). Uji keturunan generasi kedua E. pellita dibangun dengan rancangan populasi tunggal dimana famili-famili yang diuji merupakan gabungan dari berbagai provenans yang berbeda (Leksono et al., 2005). Oleh karena itu perlu dicatat di sini bahwa pengaruh variasi provenans diduga telah memberikan kontribusi yang cukup besar pada variasi famili, sehingga diduga telah memberikan bias estimasi yang lebih tinggi (over estimated) pada besarnya variasi famili.

Tabel 3. Nilai kuadrat tengah pada analisis varians terhadap sifat tinggi, diameter dan volume batang pada uji keturunan generasi kedua Eucalyptus pellita di Pelaihari dan Wonogiri umur 2 dan 4 tahun

\begin{tabular}{|c|c|c|c|c|c|c|c|}
\hline \multirow{2}{*}{ Sifat } & \multirow{2}{*}{$\begin{array}{l}\text { Sumber } \\
\text { Variasi }\end{array}$} & \multicolumn{3}{|c|}{ Pelaihari } & \multicolumn{3}{|c|}{ Wonogiri } \\
\hline & & $\mathrm{db}$ & 2 tahun & 4 tahun & $\mathrm{db}$ & 2 tahun & 4 tahun \\
\hline \multirow[t]{3}{*}{ Tinggi } & Blok & 9 & 20,1016 & 62,7622 & 3 & 1,0086 & 28,5104 \\
\hline & Famili & 48 & $3,7913^{(p<0,0003)}$ & $11,0703^{(p<0,0001)}$ & 48 & $1,3555^{(p<0,0253)}$ & $4,3380^{(p<0,0069)}$ \\
\hline & Galat & 397 & 1,9460 & 4,4721 & 131 & 0,8695 & 2,4738 \\
\hline \multirow[t]{3}{*}{ Diameter } & Blok & 9 & 4,6927 & 14,8264 & 3 & 4,0686 & 12,3936 \\
\hline & Famili & 48 & $4,0658^{(p<0,0001)}$ & $13,2762^{(p<0,0001)}$ & 48 & $1,4818^{(p<0,0704)}$ & $4,0565^{(p<0,0016)}$ \\
\hline & Galat & 397 & 1,2531 & 5,0739 & 131 & 1,0516 & 2,4738 \\
\hline \multirow[t]{3}{*}{ Volume } & Blok & 9 & 736,3472 & 8276,1113 & 3 & 0,7756 & 1150,1823 \\
\hline & Famili & 48 & $346,2201^{(p<0,0001)}$ & $8092,4585^{(p<0,0001))}$ & 48 & $3,3147^{(p<0,0420)}$ & $262,7217^{(p<0,0082)}$ \\
\hline & Galat & 397 & 133,1201 & 3093,3501 & 131 & 2,2295 & 151,2873 \\
\hline
\end{tabular}

Keterangan: Angka dalam kurung adalah nilai tingkat uji signifikansi

\section{Heritabilitas}

Hasil penghitungan estimasi nilai heritabilitas famili pada uji keturunan generasi kedua E. pellita di Pelaihari dan Wonogiri disajikan pada Tabel 4. Secara umum nilai heritabilitas famili menunjukkan nilai yang lebih besar di Pelaihari dibandingkan dengan di
Wonogiri pada seluruh sifat dan umur. Nilai heritabilitas famili di kedua lokasi plot uji keturunan termasuk kategori sedang - tinggi (Cotterill, 1987).

Besarnya nilai heritabilitas merupakan cerminan dari pengaruh variasi famili yang diuji di uji keturunan. Terdapat perbedaan nilai 
heritabilitas antarsifat pada kedua lokasi plot uji keturunan di mana diameter dan volume batang menunjukkan nilai heritabilitas yang lebih besar dibandingkan dengan tinggi tanaman, kecuali pada umur 2 tahun di Wonogiri. Hal ini sebagaimana terlihat pada lemahnya pengaruh variasi famili untuk sifat diameter dan volume batang umur 2 tahun di Wonogiri (Tabel 3) yang berdampak pada nilai heritabilitas yang paling rendah dibandingkan dengan tinggi tanaman (Tabel 4).

Tabel 4. Estimasi nilai heritabilitas famili pada uji keturunan generasi kedua Eucalyptus pellita di Pelaihari dan Wonogiri umur 2 dan 4 tahun

\begin{tabular}{lcclccc}
\hline \multirow{2}{*}{ Sifat } & \multicolumn{2}{c}{ Pelaihari } & & \multicolumn{2}{c}{ Wonogiri } \\
\cline { 2 - 3 } \cline { 5 - 6 } & 2 tahun & 4 tahun & & 2 tahun & 4 tahun \\
\hline Tinggi & 0,46 & 0,56 & & 0,34 & 0,35 \\
Diameter & 0,73 & 0,63 & & 0,28 & 0,48 \\
Volume & 0,64 & 0,61 & & 0,31 & 0,37 \\
\hline
\end{tabular}

Secara umum besarnya nilai heritabilitas menunjukkan bahwa ekspresi pengaruh variasi famili pada uji keturunan generasi kedua E. pellita terlihat lebih nyata pada lokasi dengan kondisi tapak yang cocok bagi pertumbuhan E. pellita. Hal ini sebagaimana terlihat pada besarnya nilai heritabilitas famili di lokasi Pelaihari dibandingkan dengan di Wonogiri (Tabel 4). Variasi genetik cenderung akan semakin tinggi pada populasi tanaman yang memiliki pertumbuhan yang lebih besar dan kondisi lingkungan yang lebih sesuai (Carson, 1991; Cotterill \& Dean, 1988). Namun demikian, terdapat perbedaan tren nilai heritabilitas antara umur 2 dengan 4 tahun di masing-masing lokasi. Di Pelaihari, nilai heritabilitas tinggi cenderung naik dari umur 2 tahun ke umur 4 tahun, sedangkan untuk diameter batang dan volume batang heritabilitas cenderung turun. Di Wonogiri, nilai heritabilitas cenderung naik dari umur 2 tahun ke umur 4 tahun pada semua sifat yang diamati. Hal ini diduga disebabkan karena lebih besarnya tingkat kompetisi yang terjadi antar individu tanaman di Pelaihari karena pertumbuhan tanaman yang lebih cepat sehingga menekan munculnya variasi genetik pada diameter dan volume batang (Foster, 1986; Muir, 2005).

\section{Korelasi genetik}

Hasil penghitungan nilai korelasi genetik dan korelasi fenotipik antarsifat yang diamati di kedua uji keturunan generasi kedua E. pellita disajikan pada Tabel 5. Secara umum korelasi genetik menunjukkan nilai yang lebih kuat $(>0,9)$ dibandingkan dengan korelasi fenotipik di kedua lokasi kebun benih.

Tabel 5. Hasil penghitungan nilai korelasi genetik dan korelasi fenotipik antarsifat yang diamati pada uji keturunan generasi kedua Eucalyptus pellita di Pelaihari dan Wonogiri umur 2 dan 4 tahun

\begin{tabular}{|c|c|c|c|c|}
\hline \multirow{3}{*}{ Sifat } & \multicolumn{4}{|c|}{ Umur } \\
\hline & \multicolumn{2}{|c|}{2 tahun } & \multicolumn{2}{|c|}{4 tahun } \\
\hline & Tinggi & Diameter & Tinggi & Diameter \\
\hline \multicolumn{5}{|l|}{ Pelaihari } \\
\hline$\overline{\text { Tinggi }}$ & - & 0,94 & - & 0,70 \\
\hline Diameter & 0,78 & - & 0,63 & - \\
\hline \multicolumn{5}{|l|}{ Wonogiri } \\
\hline Tinggi & - & 0,96 & - & 0,99 \\
\hline Diameter & 0,95 & - & 0,88 & - \\
\hline Keterangan: & $\begin{array}{l}\text { Angk } \\
\text { meru } \\
\text { bagia } \\
\text { nilai } 1\end{array}$ & $\begin{array}{l}\text { bagia } \\
\text { akan nilai } \\
\text { bawah } \\
\text { orelasi fen }\end{array}$ & $\begin{array}{l}\text { atas } \\
\text { relasi } \\
\text { agonal } \\
\text { pik }\end{array}$ & $\begin{array}{l}\text { diagonal } \\
\text { netik dan } \\
\text { nerupakan }\end{array}$ \\
\hline
\end{tabular}

Lemahnya korelasi genetik antara sifat diameter batang dengan tinggi tanaman pada umur 4 tahun di Pelaihari $(0,70)$ diduga sebagai dampak dari pengaruh penjarangan seleksi dalam plot yang telah dilaksanakan sebanyak dua kali (rasio penjarangan 60\%). Penjarangan seleksi dilaksanakan dengan prioritas seleksi berdasarkan tingkat pertumbuhan tanaman di dalam masing-masing plot (5 tree-plot) dan kurang mempertimbangkan jarak antar tanaman. Pengaruh pembukaan ruang tumbuh setelah penjarangan ini diduga memacu pertumbuhan diameter yang lebih cepat namun bervariatif sesuai dengan ruang tumbuh yang ada pada masing-masing famili. Sementara itu kondisi yang sama tidak terjadi pada plot uji keturunan di Wonogiri, karena pertumbuhan tanaman yang lebih lambat dan penjarangan seleksi 
dilaksanakan dengan rasio yang lebih rendah (40\%). Pada jenis ekaliptus lainnya, Kien, Jansson, Harwood, dan Thinh, (2009) juga telah melaporkan adanya pengaruh tingkat penjarangan seleksi yang tinggi terhadap distribusi variasi genetik, nilai heritabilitas dan korelasi genetik pada uji keturunan E. urophylla. Secara umum penjarangan seleksi cenderung akan melambungkan (inflated) estimasi nilai heritabilitas (Matheson \& Raymond, 1984).

Korelasi genetik antarsifat yang cukup kuat pada kedua uji keturunan ini akan memberikan implikasi terhadap efisiensi seleksi dan perolehan genetik yang dihasilkan. Kriteria seleksi berdasarkan tinggi maupun diameter batang akan memberikan nilai yang positif pada perbaikan sifat volume batang. Sebagaimana diketahui bahwa volume batang merupakan salah satu variabel pertumbuhan tanaman yang banyak digunakan sebagai tolok ukur produktivitas tegakan tanaman hutan. Namun demikian, dalam rangka seleksi multi sifat (multiple-trait selection), seleksi pada kedua uji keturunan generasi kedua E. pellita ini akan lebih efektif apabila sifat diameter batang diberikan bobot kriteria seleksi yang lebih besar dibandingkan dengan tinggi tanaman. Hal ini disamping karena nilai heritabilitas yang cenderung lebih besar (Tabel 4) dan korelasi genetik antarsifat yang tinggi, diameter batang merupakan sifat yang paling mudah untuk diukur / diamati di lapangan.

\section{Analisis multi lokasi}

\section{Analisis varians}

Analisis multi lokasi dilakukan dengan menggabungkan data dari kedua plot uji keturunan generasi kedua E. pellita di Pelaihari dengan Wonogiri. Penggabungan data dilakukan pada setiap umur pengamatan, umur 2 tahun dan 4 tahun untuk setiap sifat yang diamati, tinggi, diameter dan volume. Hasil analisis varians multi lokasi masing-masing sifat sebagaimana disajikan pada Tabel 6.

Tabel 6. Nilai kuadrat tengah pada analisis varians multi lokasi terhadap sifat tinggi, diameter, volume batang pada uji keturunan generasi kedua Eucalyptus pellita di Pelaihari dan Wonogiri umur 2 dan 4 tahun

\begin{tabular}{|c|c|c|c|c|c|}
\hline \multirow{2}{*}{$\begin{array}{l}\text { Umur } \\
\text { (tahun) }\end{array}$} & \multirow{2}{*}{ Sumber variasi } & \multirow{2}{*}{$\mathrm{db}$} & \multicolumn{3}{|c|}{ Kuadrat tengah } \\
\hline & & & Tinggi & Diameter & Volume \\
\hline \multirow[t]{5}{*}{2} & Lokasi & \multicolumn{2}{|c|}{18797,04} & 4608,14 & 180676,62 \\
\hline & Blok (Lokasi) & 12 & 15,35 & 4,68 & 60,91 \\
\hline & Famili & 48 & $3,97^{(p<0,0027)}$ & $3,93^{(p<0,0001)}$ & $256,99^{(p<0,3566)}$ \\
\hline & Famili $\times$ Lokasi & 48 & $1,17^{(p<0,9384)}$ & $1,61^{(p<0,0682)}$ & $92,53^{(p<0,6290)}$ \\
\hline & Galat & 528 & 1,67 & 1,20 & 100,64 \\
\hline \multirow[t]{5}{*}{4} & Lokasi & \multicolumn{2}{|c|}{19069,01} & 6661,17 & 2768016,25 \\
\hline & Blok (Lokasi) & 12 & 53,56 & 14,79 & 6463,81 \\
\hline & Famili & 48 & $12,90^{(p<0,0001)}$ & $12,89^{(p<0,0002)}$ & $6455,84^{(p<0,1725)}$ \\
\hline & Famili $\times$ Lokasi & 48 & $2,50^{(p<0,9758)}$ & $4,44^{(p<0,4307)}$ & $1899,23^{(p<0,8249)}$ \\
\hline & Galat & 528 & 3,97 & 4,33 & 2363,41 \\
\hline
\end{tabular}

Keterangan: Angka dalam kurung adalah nilai tingkat uji signifikansi

Secara umum pada analisis multi lokasi, famili menunjukkan perbedaan yang sangat nyata pada seluruh sifat yang diamati, kecuali volume batang. Tingginya pengaruh famili pada analisis multi lokasi ini juga merupakan cerminan dari tingginya pengaruh famili pada masing-masing lokasi (Tabel 3). Perbedaan umur dan lokasi mampu mempertahankan besarnya variasi genetik yang ada pada uji keturunan generasi kedua E. pellita. Secara umum perbedaan pertumbuhan tanaman karena umur (2 dan 4 tahun) dan tingkat kesuburan tapak pada masing-masing lokasi tidak mengurangi besarnya variasi genetik.

Hasil pengamatan interaksi antara faktor genetik dan lingkungan menunjukkan bahwa 
secara umum interaksi tidak memberikan pengaruh yang nyata. Hal ini menunjukkan bahwa kinerja famili relatif stabil pada kedua lokasi uji keturunan walaupun terdapat perbedaan kondisi tapak. Di samping itu perbedaan ratio penjarangan seleksi dalam plot yang telah dilakukan juga tidak memberikan pengaruh yang nyata terhadap kestabilan genetik E. pellita. Shelbourne (1972) menyatakan bahwa variasi karena adanya interaksi genetik dengan lingkungan akan memberikan dampak yang cukup besar dalam pelaksanaan seleksi apabila besarnya proporsi rasio interaksi terhadap variasi famili melebihi angka $50 \%$. Dalam penelitian ini rasio interaksi famili $\times$ lokasi terhadap variasi famili cukup rendah pada semua sifat, yaitu berkisar $11 \%$ $48 \%$ pada umur 2 tahun, dan 3\%-24\% pada umur 4 tahun.

Kestabilan famili pada kedua lokasi plot uji keturunan juga terlihat dari tingginya nilai korelasi genetik Tipe-B (Tabel 7). Secara umum korelasi Tipe-B dari dua uji keturunan generasi kedua E. pellita menunjukan nilai yang lebih besar untuk sifat tinggi tanaman $(>0,85)$ diikuti oleh volume batang dan diameter.

Tabel 7. Korelasi genetik Tipe-B pada analisis multi lokasi uji keturunan generasi kedua Eucalyptus pellita umur 2 dan 4 tahun di Pelaihari dan Wonogiri

\begin{tabular}{cccc}
\hline $\begin{array}{c}\text { Umur } \\
\text { (tahun) }\end{array}$ & Tinggi & Diameter & $\begin{array}{c}\text { Volume } \\
\text { Batang }\end{array}$ \\
\hline 2 & 0,89 & 0,74 & 0,67 \\
4 & 0,94 & 0,80 & 0,87 \\
\hline
\end{tabular}

Korelasi genetik pada umur 4 tahun menunjukkan nilai yang lebih besar dibandingkan umur 2 tahun. Sifat dengan variasi famili yang besar dan interaksi famili $\times$ lokasi yang lemah cenderung memiliki nilai korelasi genetik yang lebih tinggi. Kuatnya nilai korelasi ini memberikan indikasi besarnya potensi pemanfaatan informasi kinerja famili dari kedua lokasi dalam pelaksanaan seleksi uji keturunan generasi kedua E. pellita. Sebagaimana disampaikan oleh Bourdon (1977); White dan
Hodge (1989), bahwa efisiensi seleksi melalui analisis multi lokasi juga dipengaruhi oleh besarnya korelasi genetik yang dihitung berdasarkan hasil korelasi genetik Tipe-B.

\section{Heritabilitas}

Hasil estimasi heritabilitas famili pada analisis multi lokasi dua uji keturunan generasi kedua E. pellita disajikan pada Tabel 8. Secara umum besarnya nilai heritabilitas masuk kategori sedang - tinggi dan sedikit bervariatif antar tiga sifat yang diamati. Namun demikian, nilai heritabilitas masing-masing sifat relatif stabil pada dua umur tanaman.

Tabel 8. Estimasi nilai heritabilitas famili pada analisis multi lokasi uji keturunan generasi kedua Eucalyptus pellita umur 2 dan 4 tahun di Pelaihari dan Wonogiri

\begin{tabular}{cccc}
\hline $\begin{array}{c}\text { Umur } \\
\text { tahun) }\end{array}$ & Tinggi & Diameter & $\begin{array}{c}\text { Volume } \\
\text { batang }\end{array}$ \\
\hline 2 & 0,76 & 0,54 & 0,65 \\
4 & 0,86 & 0,65 & 0,74 \\
\hline
\end{tabular}

Nilai heritabilitas tertinggi ditemukan pada sifat tinggi tanaman, diikuti oleh volume batang dan diameter. Hal ini mencerminkan bahwa pada analisis multi lokasi sifat tinggi tanaman memiliki variasi genetik yang lebih besar dibandingkan dengan kedua sifat lainnya. Kondisi ini berbeda dengan nilai heritabilitas pada analisis satu lokasi di mana tinggi menunjukkan nilai yang lebih rendah (Tabel 4). Penggabungan data dua lokasi pada analisis multi lokasi lebih meningkatkan variabilitas pada sifat tinggi tanaman dibandingkan dengan diameter dan volume batang. Di samping itu, walaupun interaksi famili $\times$ lokasi tidak menunjukkan pengaruh yang nyata (Tabel 6), semakin melemahnya interaksi, sebagaimana ditunjukkan naiknya nilai $p$, cenderung akan menaikkan estimasi heritabilitas famili.

\section{Rangking famili}

Hasil penghitungan rangking famili dilaksanakan dengan mengacu pada 2 model, yaitu 1) model seleksi langsung (direct selection) berdasarkan data famili terpilih pada 
masing-masing lokasi, dan 2) model gabungan (combined selection) familli terpilih berdasarkan data gabungan dari dua lokasi uji keturunan. Selanjutnya nilai indeks untuk menentukan rangking famili dihitung menggunakan indeks seleksi multi sifat (multiple traits-selection index) berdasarkan dua sifat yang diamati yaitu tinggi dan diameter.

Hasil penentuan rangking famili berdasarkan nilai indeks seleksi multi-sifat menunjukkan bahwa secara umum rangking famili dari 49 famili umur 2 tahun dan 4 tahun menunjukkan kestabilan yang bervariatif, walaupun hasil analisis varians berdasarkan satu sifat menunjukkan interaksi famili dan lokasi tidak berbeda nyata (Tabel 6). Kisaran deviasi rata-rata famili, yaitu deviasi antara rangking famili pada seleksi langsung terhadap rangking famili pada seleksi gabungan, juga bervariatif. Sebagian besar jumlah famili berada pada kisaran deviasi $25 \%-50 \%$. Sementara itu hanya sebagian kecil ( $<10$ famili) berada pada kisaran deviasi di atas 50\%. Ditemukannya beberapa famili yang interaktif pada penelitian ini memberikan indikasi bahwa walaupun interaksi famili $\times$ lokasi tidak berbeda nyata berdasarkan analisis satu sifat (Tabel 6), perubahan rangking famili masih bisa terjadi pada analisis multisifat (Namkoong, Kang, \& Brouard, 1988).

Korelasi nilai indeks rangking famili satu lokasi terhadap nilai indeks rangking famili

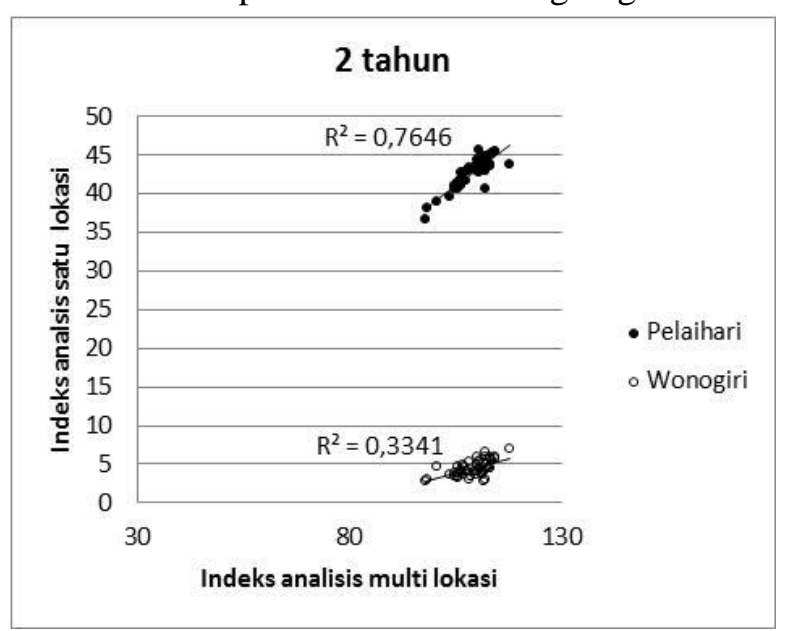

gabungan multi lokasi (Gambar 1) juga menunjukkan bahwa nilai korelasi uji keturunan di Pelaihari lebih besar $(r=0,87-0,92)$ dibandingkan nilai di Wonogiri $(\mathrm{r}=0,57-0,81)$ pada kedua umur pengamatan. Nilai korelasi semakin tinggi pada umur 4 tahun dibandingkan pada umur 2 tahun. Semakin tinggi nilai koefisien korelasi akan mencerminkan semakin tingginya kesesuaian dan kestabilan rangking famili pada satu lokasi uji keturunan terhadap rangking famili gabungan kedua lokasi. Hal ini menunjukkan bahwa rangking famili pada uji keturunan generasi kedua E. pellita relatif stabil walaupun terdapat perbedaan kondisi tapak yang sangat ekstrem dan kondisi lain yang memungkinkan terjadinya ekspresi genetik yang bervariatif, seperti semakin tua umur tanaman dan potensi peningkatan kompetisi antar individu tanaman atau mortalitas (Foster, 1986).

\section{Perolehan genetik}

Perolehan genetik dihitung berdasarkan tiga model seleksi pada analisis multi lokasi, yaitu 1) perolehan genetik sebagai hasil dari seleksi langsung (direct selection), 2) perolehan genetik sebagai hasil dari seleksi tidak langsung (indirect selection), 3) perolehan genetik sebagai hasil dari seleksi gabungan dua lokasi (combined selection). Hasil perolehan genetik pada dua uji keturunan generasi kedua E. pellita umur 2 dan 4 tahun disajikan pada Gambar 2.

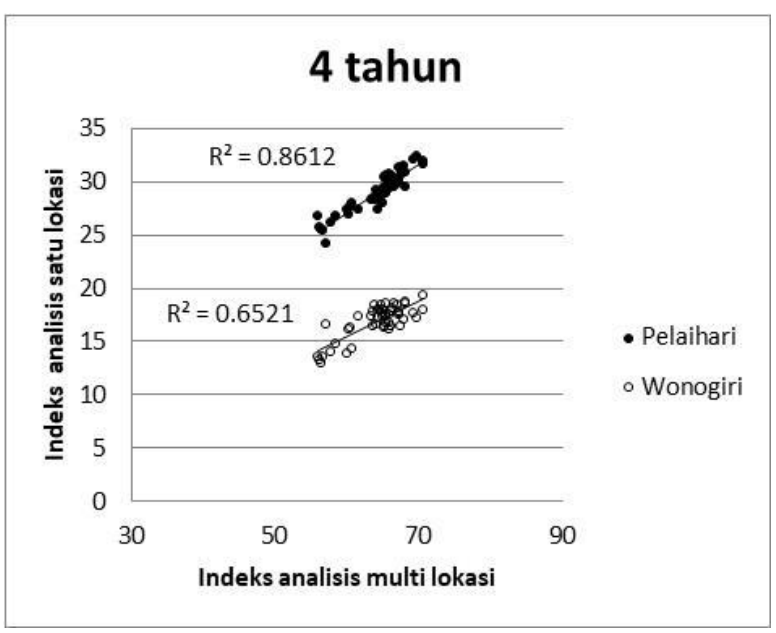

Gambar 1. Korelasi antara indeks analisis satu lokasi terhadap indeks analisis multi lokasi pada dua plot uji keturunan generasi kedua Eucalyptus pellita umur 2 tahun dan 4 tahun 

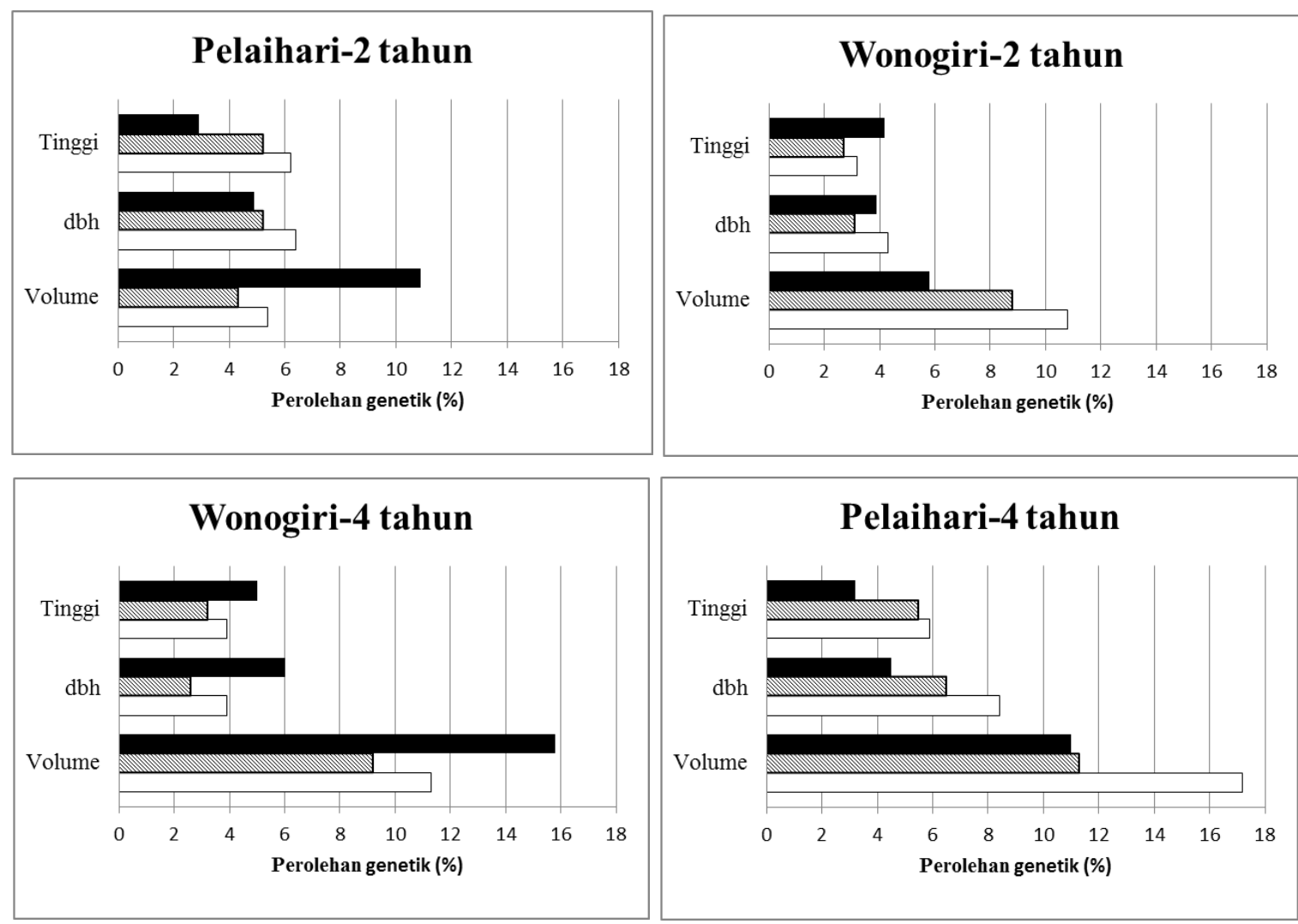

Keterangan: $\quad$ dbh $=$ diameter setinggi dada

Gambar 2. Perolehan genetik pada dua uji keturunan generasi kedua Eucalyptus pellita umur 2 tahun dan 4 tahun di Pelaihari dan Wonogiri. ( $\square$ seleksi langsung, $\square$ seleksi tidak langsung, $\square$ seleksi gabungan)

Secara umum perolehan genetik umur 4 tahun menunjukkan nilai lebih besar dibandingkan umur 2 tahun dengan nilai tertinggi ditemukan pada volume batang. Nilai perolehan genetik hasil seleksi langsung terbesar ditemukan pada uji keturunan di Wonogiri untuk sifat volume batang umur 4 tahun $(15,8 \%)$ dan terendah pada uji keturunan di Pelaihari untuk sifat tinggi umur 2 tahun $(2,9 \%)$. Namun demikian besarnya perolehan genetik volume batang di Wonogiri ini diduga lebih disebabkan adanya efek perbedaan ukuran skala metriknya (scale effect). Hal ini sebagaimana terlihat perbedaan volume batang di Pelaihari 6 kali lebih besar dibandingkan volume batang di Wonogiri pada umur 4 tahun (Tabel 2). Zobel dan Talbert (1984) menyatakan bahwa karena adanya perbedaan ukuran pertumbuhan yang cukup besar, persentase superioritas cenderung melonjak tinggi pada volume batang pada pohon ukuran kecil dibandingkan pohon ukuran besar.

Walaupun interaksi tidak berbeda nyata (Tabel 6), adanya beberapa famili yang interaktif di kedua lokasi berdasarkan nilai indeks seleksi multi-sifat telah memberikan pengaruh pada nilai perolehan genetik yang bervariatif baik antarsifat maupun antar umur. Sebagai perbandingan, nilai perolehan genetik uji keturunan generasi kedua E. pellita pada penelitian ini lebih kecil dibandingkan perolehan genetik uji keturunan generasi pertama E. pellita umur 20 bulan di Pelaihari dimana perolehan genetik berkisar $6 \%-7 \%$ untuk sifat tinggi dan diameter (Kurinobu, Nirsatmanto, \& Leksono, 1996). Perbedaan nilai perolehan genetik ini diduga karena turunnya variasi genetik yang terjadi pada uji keturunan generasi kedua. Hal ini sebagaimana ditunjukkan jumlah famili pada generasi 
pertama sebanyak 117 famili (Kurinobu et al., 1996), sedangkan jumlah famili terseleksi yang digunakan pada generasi kedua dalam penelitian ini sebanyak 49 famili. Zobel dan Talbert (1984) menyatakan bahwa jumlah famili yang tidak berkerabat (unrelated) cenderung semakin kecil seiring dengan peningkatan generasi pemuliaan yang dilampaui.

Analisis multi lokasi memberikan dampak positif yang lebih besar terhadap seleksi famili pada uji keturunan di Pelaihari sebagaimana ditunjukkan dengan semakin besarnya perolehan genetik pada seleksi tidak langsung dan seleksi gabungan dibandingkan dengan seleksi langsung (Gambar 2). Sementara itu analisis multi lokasi tidak memberikan perolehan genetik yang lebih baik terhadap seleksi pada uji keturunan di Wonogiri, khususnya pada umur 4 tahun dimana perolehan genetik analisis tidak langsung maupun gabungan menunjukkan nilai yang lebih rendah dibandingkan analisis langsung. Hal ini terjadi diduga karena adanya perbedaan besarnya variabilitas genetik diantara kedua lokasi (Yamada, 1962). Uji keturunan di Pelaihari memiliki variabilitas yang lebih besar dibandingkan dengan Wonogiri, sebagaimana terlihat dari nilai heritabilitasnya (Tabel 4).

Pada umur 2 tahun, seleksi tidak langsung dan seleksi gabungan memberikan nilai perolehan genetik yang bervariatif pada masingmasing sifat dan lokasi, sedangkan pada umur 4 tahun kedua model seleksi menunjukkan respon yang spesifik pada masing-masing lokasi. Seleksi tidak langsung dan seleksi gabungan memberikan nilai perolehan genetik yang rendah pada uji keturunan di Wonogiri. Sebaliknya seleksi tidak langsung maupun seleksi gabungan mampu memberikan nilai perolehan yang lebih besar pada uji keturunan di Pelaihari. Hal ini menunjukkan bahwa walaupun secara statistik interaksi famili $\times$ lokasi tidak ada, seleksi famili pada dua kebun benih generasi kedua E. pellita memerlukan kombinasi dan arah seleksi yang tepat. Dengan kata lain bahwa seleksi berdasarkan data gabungan kedua lokasi uji keturunan akan lebih menguntungkan pada pasangan lokasi yang memiliki variabilitas genetik yang lebih besar.

Secara umum uji keturunan di Wonogiri merupakan pasangan yang optimal untuk digunakan sebagai kriteria seleksi pada uji keturunan di Pelaihari pada semua sifat yang diamati. Namun demikian analisis gabungan kedua lokasi mampu memberikan perolehan genetik yang lebih besar dibandingkan seleksi tidak langsung pada semua sifat dan umur di Pelaihari. Hal ini menunjukkan bahwa walaupun kedua lokasi memiliki perbedaan kondisi lingkungan yang cukup besar baik secara klimatologis maupun edaphis (Tabel 1), penggabungan data dari kedua lokasi uji keturunan mampu meningkatkan variasi antar famili yang diuji sehingga meningkatkan nilai perolehan genetiknya. Peningkatan besarnya variasi sebagaimana terlihat dari nilai heritabilitas famili pada analisis multi lokasi (Tabel 7) dibandingkan nilai heritabilitas pada analisa satu lokasi (Tabel 4).

Perolehan genetik merupakan tolok ukur yang sangat penting dalam melihat efektifitas seleksi dan optimalisasi pengaruh interaksi genetik $\times$ lingkungan pada uji keturunan generasi kedua $E$. pellita. Tidak adanya interaksi famili $\times$ lokasi pada uji keturunan generasi kedua $E$. pellita pada penelitian ini (Tabel 6) memberikan indikasi efektifitas yang lebih tinggi apabila seleksi dilaksanakan melalui kombinasi data dari kedua lokasi plot uji keturunan, baik melalui seleksi tidak langsung maupun seleksi gabungan. Dampak efektivitas seleksi ini terlihat cukup nyata khususnya pada seleksi uji keturunan di Pelaihari. Nilai perolehan genetik hasil seleksi gabungan terbesar ditemukan pada sifat volume batang umur 4 tahun di Pelaihari, yaitu sebesar 17,2\% (Gambar 2). Beberapa penelitian juga melaporkan diperolehnya efektivitas seleksi yang lebih tinggi melalui penggabungan data dari beberapa lokasi uji keturunan: jenis E. urophylla (Nirsatmanto et al., 1996), 
A. mangium (Nirsatmanto, Suhaendi, \& Charomaini, 1996; Setyaji, 2013).

\section{KESIMPULAN}

Interaksi famili $\times$ lokasi pada uji keturunan generasi kedua $E$. pellita umur 2 dan 4 tahun di Pelaihari dan Wonogiri tidak menunjukkan pengaruh yang nyata untuk sifat tinggi, diameter dan volume batang. Secara umum seleksi famili melalui penggabungan data dari kedua lokasi uji keturunan akan lebih efektif dalam meningkatkan nilai perolehan genetik. Analisis multi lokasi melalui seleksi gabungan (combined selection) dua uji keturunan maupun seleksi tidak langsung (indirect selection) memberikan efektivitas seleksi yang lebih besar dibandingkan seleksi langsung (direct selection) untuk uji keturunan di Pelaihari umur 4 tahun dengan peningkatan nilai perolehan genetik mencapai $\pm 50 \%$.

\section{UCAPAN TERIMA KASIH}

Tulisan merupakan bagian dari studi S-2 Penulis pada Pasca Sarjana Universitas Gadjah Mada. Ucapan terima kasih penulis sampaikan kepada Tim Peneliti Pemuliaan Akasia, Ekaliptus dan Jabon: Dr. Sri Sunarti, Teguh Setyaji S. Hut, M. Sc, Surip, S. Hut, M. Sc, Dwi Kartikaningtyas, S. Hut, Bety Rahma handayani, S. Hut, M. Sc, Dwi Siwi Y S. Hut., dan Maryono yang membantu dalam pengumpulan serta analisis data.

\section{DAFTAR PUSTAKA}

Bourdon, R. D. (1977). Genetic Correlation as a Concept for Studing Genotype-Enviroment Interaction inf Forest Tree Breeding. Silvae Genética, 6, 5-6.

Brawner, J. T., Bush, D. J., Macdonell, P. F., Warburton, P. M., \& Clegg, P. A. (2010). Genetic parameters of red mahogany breeding populations grown in the tropics. Australian Forestry, 73(3), 177-183. https://doi.org/10.1080/00049158.2010.1067 6324

Brawner, J. T., Japarudin, Y., Lapammu, M., Rauf, R., Boden, D., \& Wingfield, M. J. (2015). Evaluating the inheritance of Ceratocystis acaciivora symptom expression in a diverse Acacia mangium breeding population. Southern Forests: A Journal of Forest Science, 77(1), 83-90. https://doi.org/10.2989/20702620.2015.1007 412

Burdon, R. D. (1979). Generalisation of multi-trait selection indices using information from several sites. New Zealand Journal of Forestry Science, 9(2), 145-152.

Carson, S. D. (1991). Genotype x environment interaction and optimal number of progeny test sites for improving Pinus radiata pine in New Zealand. New Zealand Journal of Forestry Science, 21(1), 32-49.

Clutter, J. L., Fortson, J. C., Pienaar, L. V., Britste, G. H., \& Bailey, R. L. (1983). Timber Management: Quantitative Approach. New York, USA: John Willey \& Sons.

Cotterill, P. P. (1987). Short Note: On estimating heritability according to practical applications. Silvae Genetica.

Cotterill, P. P., \& Dean, C. A. (1988). Changes in the genetic control of growth of radiata pine to 16 years and efficiencies of early selection. Silvae Genetica, 37(3-4), 138-146. Retrieved from

https://www.thuenen.de/media/institute/fg/P DF/Silvae_Genetica/1988/Vol._37_Heft_34/37_3-4_138.pdf

Foster, G. S. (1986). Trends in genetic parameters with stand development and their influence on early selection for volume growth in Loblolly pine. Forest Science (Vol. 32).

Hardiyanto, E. B. (2003). Growth and genetic improvement of Eucalyptus pellita in South Sumatra, Indonesia. In J. W. Turnbull (Ed.), Eucalypts in Asia (pp. 82-88). Zhanjiang, Guangdong, People's Republic of China.

Harwood, C. E., Hardiyanto, E. B., \& Yong, W. C. (2015). Genetic improvement of tropical acacias: achievements and challenges. Southern Forests: A Journal of Forest Science, 77(1), 11-18. https://doi.org/10.2989/20702620.2014.9993 02

Harwood, C. E., \& Nambiar, E. K. S. (2014). Sustainable plantation forestry in South-East Asia. Canberra.

Hazel, L. N. (1943). The genetic basis for constructing selection indexes. Genetics, 28, 476-490.

House, A. P. N., \& Bell, J. C. (1996). Genetic diversity, mating system and systematic 
relationships in two red mahoganies, Eucalyptus pellita and E. scias. Australian Journal of Botany - AUST J BOT (Vol. 44). https://doi.org/10.1071/BT9960157

Hung, T. D., Brawner, J. T., Meder, R., Lee, D. J., Southerton, S., Thinh, H., \& Dieters, M. (2014). Estimates of genetic parameters for growth and wood properties in Eucalyptus pellita F. Muell. to support tree breeding in Vietnam. Annals of Forest Science (Vol. 72). https://doi.org/10.1007/s13595-014-0426-9

Johnson, I. G. (1992). Family site interactions in radiata pine families in new south wales australia. Silvae Genetica, 41(1), 55-62. Retrieved from https://eurekamag.org/research/007/343/0073 43955.php

Kien, N. D., Jansson, G., Harwood, C., \& Thinh, H. H. (2009). Genetic control of growth and form in Eucalyptus urophylla in Northern Vietnam. Journal of Tropical Forest Science, 21(1), 50-65. Retrieved from http://www.jstor.org/stable/23616562

Kurinobu, S., Nirsatmanto, A., \& Leksono, B. (1996). Prediction genetic gain by within-plot selection in seedling seed orchards of Acacia mangium and Eucalyptus with application of retrospective selection index: Tree improvement for sustainable tropical forestry. In M. J. Dieters, A. C. Matheson, D. G. Nikles, C. E. Hrwood, \& S. M. Walker (Eds.), QFRI-IUFRO Conf. (pp. 158-163). Caloundra, Queensland, Australia: Queensland Forestry Research Institute, Gympie.

Kurinobu, S., \& Rimbawanto, A. (2002). Genetic improvement of plantation species in Indonesia-Summary of Project Achievement (JICA Forest Tree Improvement Phase II). In A. Rimbawanto \& M. Susanto (Eds.), Proceedings of international conference on advances in genetic improvement of tropical tree species, 1-3 October 2002, Yogyakarta, Indonesia. Yogyakarta: Centre for Forest Biotechnology and Tree Improvement.

Leksono, B. (2009). Breeding zones based on genotype-environment interaction in seedling seed orchards of Eucalyptus pellita in Indonesia. Journal of Forestry Research, 6(1), 74-84.

Leksono, B., Nirsatmanto, A., Setyaji, T., \& Surip. (2005). General information of seed source (F-2) of A. mangium, A. crassicarpa and E. pellita establishment in Wonogiri, Central Java. Yogyakarta.
Matheson, A. C., \& Raymond, C. A. (1984). The impact of genotype $\mathrm{x}$ environment interactions on Australian Pinus radiata breeding programs. Australian Forest Research, 14, 11-25. Retrieved from https://epubs.scu.edu.au/cpcg_pubs/615/

Muir, W. M. (2005). Incorporation of competitive effects in forest tree or animal breeding programs. Genetics, 170(3), 1247-1259. https://doi.org/10.1534/genetics.104.035956

Namkoong, G., Kang, H. C., \& Brouard, J. S. (1988). Tree breeding: principles and strategies. Springer-Verlag.

Nirsatmanto, A., Seido, K., Kurinobu, S., Na'iem, M., Hardiyanto, E. B., \& Suseno, O. H. (1996). Analysis of provenance-progeny tests of Eucalyptus urophylla established at two locations in Indonesia. In M. J. Dieters, A. C. Matheson, D. G. Nikles, C. E. Harwood, \& S. M. Walker (Eds.), Tree improvement for sustainable tropical forestry: Proceeding of the QFRI-IUFRO Conference, Caloundra, Australia. 27 October - 1 November 1996ent for Sustainable Tropical Forestry. Proceedings of QFRI-IUFRO Conference (pp. 206-207). Caloundra, Queensland, Australia: Queensland Forestry Research Institute, Gynpie.

Nirsatmanto, A., Suhaendi, H., \& Charomaini, M. (1996). Investigation on family - site interaction of Acacia mangium seedling seed orchard established at two locations in Indonesia. In A. Rimbawanto, A. Widyatmoko, H. Suhaendi, \& T. Furukoshi (Eds.), International Seminar Proceeding: Tropical Plantation Establishment, Improving Productivity Through Genetic Practices (pp. 12-18). Yogyakarta, Indonesia: Forest Tree Improvement Research and Development Institute-Japan International Cooperation Agency.

Pinyopusarerk, K., \& Harwood, C. E. (2010). Advanced-generation breeding and deployment of Acacia and Eucalyptus species and hybrids in Some Asian Countries. In H. C. Sim, L. T. Hong, \& R. Jalonen (Eds.), International Symposium on Forest Genetic Resources-Conservation and Sustainable Utilization towards climate change mitigation and adaptation (pp. 104-107). Kuala Lumpur, Malaysia: FRIM, APAFRI and Bioversity International.

Setyaji, T. (2013). Interaksi famili x lokasi pada uji keturunan generasi kedua Acacia mangium di Sumatera dan Kalimantan. Jurnal Pemuliaan 
Tanaman Hutan, 7(1), 41-52. https://doi.org/10.20886/jpth.2013.7.1.41-52

Shelbourne, C. J. A. (1972). Genotype-environment interaction: its study and its implications in forest tree improvement. In IUFRO GeneticsSABRAO Joint Symposia (p. B-1(I), 1-28). Tokyo, Japan: The Government Forest Experiment Station of Japan.

Sunarti, S., Na'iem, M., Hardiyanto, E. B., \& Indrioko, S. (2013). Breeding strategy of Acacia Hybrid (Acacia mangium $\times A$. auriculiformis) to increase forest plantation productivity in Indonesia. Jurnal Manajemen Hutan Tropika (Journal of Tropical Forest Management), XIX(2), 128-137. https://doi.org/10.7226/jtfm.19.2.128

Tarigan, M., Roux, J., Van Wyk, M., Tjahjono, B., \& Wingfield, M. J. (2011). A new wilt and dieback disease of Acacia mangium associated with Ceratocystis manginecans and $C$. acaciivora sp. nov. in Indonesia. South African Journal of Botany, 77(2), 292-304. https://doi.org/10.1016/j.sajb.2010.08.006
White, T. L., \& Hodge, G. R. (1989). Predicting breeding values with applications in forest tree improvement (Vol. 33). Springer Netherlands. Retrieved from https://link.springer.com/book/10.1007\%2F9 78-94-015-7833-2

Wright, J. W. (1976). Introduction to forest genetics (United Kin). New York San Francisco: Academic Press Inc. (London) LTD. https://doi.org/10.1016/B978-0-12-7652504.50023-X

Yamada, Y. (1962). Genotype by environment interaction and genetic correlation of the same trait under different environments. 遺伝學雑誌， 37(6)， 498-509. https://doi.org/10.1266/jjg.37.498

Zobel, B., \& Talbert, J. (1984). Applied forest tree improvement. New York, Brisbane, Toronto, Singapore: John Willey and Sons. 
Jurnal Pemuliaan Tanaman Hutan

Vol. 11 No. 2, Desember 2017, p. 25 - 39 